\title{
APORTES PARA LA CONSTRUCCIÓN DE TEORÍAS DEL VIDEOJUEGO
}

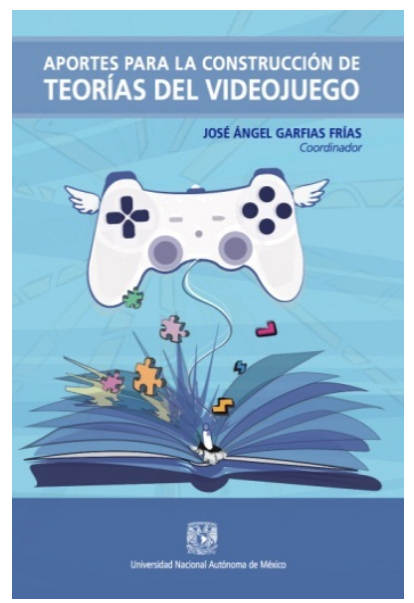

GARFIAS, JOSÉ (COORD.). APORTES PARA LA CONSTRUCCIÓN DE TEORÍAS DEL VIDEOJUEGO, UNIVERSIDAD NACIONAL AUTÓNOMA MÉXICO, FCPYS, MÉXICO, 2017. 145 PÁGS. ISBN: 978-607-02-9760-1

\author{
Jimena Yisel Caballero Contreras \\ (Universidad Autónoma de México, México) \\ jimenayisel@politicas.unam.mx
}

Recibido: 4/ 6/ 2017

Aprobado: 11/10/2017

Nuevas formas de interacción social, cambios en la concepción de la comunicación, pioneros en el desarrollo tecnológico del mundo, creadores de torneos con millones de comunidades, inspiración de nuevos estudios de género, transformadores de la economía global. Quién diría que los videojuegos dejarían de ser simples juegos.

Actualmente la concepción de los videojuegos como un objeto de investigación serio, digno de recibir atención de la comunidad científica, es una necesidad.

Como resultado de la labor rigurosa de reunir a los mejores investigadores en videojuegos de México, el doctor José Ángel Garfias Frías presenta en forma de libro, los frutos del proyecto Los videojuegos como industria cultural. Aporte para la construcción de teorías del videojuego, mismo que llevó dos años siendo parte del Programa de Apoyo a Proyectos de Investigación e Innovación Tecnológica (PAPIIT-IA302516).

Este libro se compone de siete capítulos, cada uno escrito por un investigador diferente, donde desde sus especialidades, realizan un estudio de caso concreto dando el primer acercamiento sobre a partir de qué ámbitos se debería comenzar a trabajar para la realización formal de teorías del videojuego.

El primer capítulo se titula El camino a las teorías del videojuego, escrito por el coordinador del libro José Ángel Garfias Frías; doctor en Ciencias Políticas y Sociales por la UNAM, pionero en el desarrollo de la línea de investigación de videojuegos en diversas instituciones de México. Su capítulo, a modo de introducción, comparte un estado del arte en la investigación de videojuegos, desde su aparición en el mundo, hasta la actualidad.

El segundo capítulo titulado Imagen - juego: Pensamiento y movimiento en las imágenes gráficas para videojuegos, de la doctora Blanca López Pérez quien, gracias a sus especialidades en Comunicación Visual, Diseño y Artes Plásticas, comparte el aporte de la producción visual en el área de los videojuegos a través de la comprensión de las imágenes como un lenguaje específico, en el mundo de la interacción usuario-plataforma.

El tercer capítulo Juego, pasado y tecnología: un acercamiento al estudio de la escenificación histórica en un entorno lúdico, comparte al estudio de los videojuegos una metodología que permite 
explicar las evocaciones al pasado que realizan los desarrolladores, como recurso creativo. El autor Germán Sosa Castañón trabaja desde sus áreas: escenificación histórica, tecnología y semiótica social.

En cuarto capítulo del maestro Roberto Carlos Rivera Mata, La evolución visual del videojuego, se logra realizar un recuento histórico de los cambios que los videojuegos han tenido respecto a su formato visual, de la mano con los cambios tecnológicos. Gracias a su especialidad en el ámbito audiovisual, incorpora además los estudios semióticos para el análisis de los videojuegos, área que no puede faltar en las teorías aplicables a dicho fenómeno.

El quinto capítulo Los videojuegos de Shigueru Miyamoto desde la teoría del autor, es una revisión a profundidad de la vida y obra de uno de los creadores de videojuegos más trascendentales, si no es que el más trascendental, de la historia de los videojuegos. Con sus estudios temporales en Tokio University of Foreing Studies en Tokio, Japón, el autor de este artículo, Sergio Valdivia Velázquez, comparte una visión global, a través de la teoría del autor, de todo lo que el arte de Miyamoto trajo al mundo.

En el sexto capítulo del doctorante en Ciencias Políticas y Sociales, David Cuenca Orozco, Uso de videojuegos al interior de la Ciudad de México: un análisis de la cultura gamer y el consumo de tecnologías digitales interactivas, donde se muestra a detalle un estudio de caso que, bajo las metodologías de observaciones y entrevistas a profundidad, concede una visión de cómo realizar un análisis riguroso en el ámbito social y cultural de los videojugadores.

Finalmente, el séptimo capítulo, Experiencias de trabajo-aprendizaje en juego como práctica emancipadora, del Maestro Jacinto Quesnel Álvarez, Fundador del Foro Internacional del Videojuego (DEVHR) muestra desde el carácter lúdico de los videojuegos, y como su diseño hoy en día es una herramienta pedagógica de suma importancia.

Como se puede observar, el libro Aportes para la construcción de teorías del videojuego le hace justicia a su nombre. Las teorías, metodologías y visiones que los autores utilizaron para realizar sus contribuciones a la obra, dejan ver las múltiples posibilidades que se tiene para comenzar a formar una visión global de lo que en un futuro puede llegar a ser una corriente teórica enfocada completamente en los videojuegos.

Mientras se da el caso, la presente obra tiene material y bibliografía basta para que los futuros investigadores en videojuegos de todo el mundo puedan comenzar a elaborar sus propias propuestas, ya que ofrece desde cómo se conciben los videojuegos, cómo se pueden estudiar, cuál es su importancia técnica y/o cultural, entre muchas otras aportaciones; siempre teniendo en cuenta que el fenómeno videogame no es sólo un juego, sino una materia transdisciplinar del siglo XXI. 